\title{
Natural diet of deep-water rose shrimp in the Beni-Saf Bay (Western Algeria)
}

\author{
A.M. Benallal ${ }^{1}$, A. Baaloudj ${ }^{2}$, A. Kerfouf ${ }^{2}$, M.A. Bouzidi ${ }^{1}$, K.Belhadj Tahar ${ }^{1}$ \\ ${ }^{1}$ Laboratory of Space Eco-Development, Djillali Liabes University, Sidi Bel Abbes 22000, Algeria \\ ${ }^{2}$ Laboratory of Biology, Water and Environment (LBEE), Guelma University, Guelma 24000, Algeria
}

*Corresponding author E-mail: bafef@yahoo.fr

Received: 14.08.2020. Accepted: 14.09.2020

\begin{abstract}
The deep-water rose shrimp, Parapenaeus longirostris (Lucas, 1846) is one of the Decapod crustacean species that is targeted by coastal and deep-sea demersal fisheries in the western Mediterranean, in the Algerian west coast in particular. Despite its socioeconomic importance and commercial interest across the country, there were only few studies focusing on its biology and ecology and no species development plan has been drawn up for now. Our study of the rose shrimp diet was based on the analysis of the faunistic composition of the ingested prey. Seasonal sampling was carried out at Béni Saf port (western Algeria) during 2018-2019, from landings from inshore trawling fisheries. A total of 641 individuals were analyzed, while taking account of males and females and size classes. Results of stomach content analyzes showed a wide range of benthic and endobenthic species. Crustacea are the preferred prey $(\mathrm{F}=77.69 \%)$, followed by Foraminifera, Annelida Polychaeta, and Mollusca with respective frequencies of (77.22\%, $58.50 \%$ and $52.73 \%$ ). Radiolaria, Porifera and Echinodermata represent a less important part in the diet of this species and constitute accidental prey, whose frequency is less than $10 \%$. Benthic organisms with silt ingest the plant and various debris, which are the secondary prey with an average frequency of $14.81 \%$.
\end{abstract}

Keywords: Parapenaeus longirostris, Red shrimp; Diet; Benthic species; Mediterranean; Beni Saf; West Algeria

\section{Introduction}

In Algeria, the abundance and frequency of Parapenaeus longirostris (Lucas, 1846), drew attention due to their high nutritional value and exceptional gastronomic quality of their flesh, thus promoting research on its distribution and on the nature of the characteristic sea beds (Nouar, 1985; Ainouche, 2009; Gheid, 2015) These sea beds are described by Maurin (1962 and 1968) in his report on the "Thalassa" campaign. It represents an important part in the landings at the level of many Algerian fishing ports. During 2019, a quantity of shrimp, approximately 70 tonnes, were landed at the port of Béni Saf (41.62 tonnes of white shrimp, 8.97 tonnes of red shrimp and 10.32 tonnes of small shrimp), (DPRH, 2019). Parapenaeus longirostris lives on sandy mud bottoms from $220 \mathrm{~m}$ to $460 \mathrm{~m}$ (Nouar, 1985). This resource is targeted by a non-specialized trawl fishing fleet, operating near the coast with traditional fishing units and by a deep-sea fishing fleet with a very wide range of action and it represents one of the most common species in the Mediterranean fishery (Ragonese et al., 2006). On the biological and fishing level, there is few works with fragmentary data (Benkabouche, 2015). This species has been studied in several areas of the Mediterranean basin, such as Spain (Froglia, 1982), Italy (Ragonese, 2000 and 2006), frensh Mediterranean Sea (Lagardere, 1975) and on the Algerian coasts (Nouar, 1985 and 2001). There are also few studies on the diet of rose shrimp (Ghidalia \& Bourgeois, 1961; Massuti, 1959; Lbropoulou \& Kostikas, 1999; Kapiris, 2004; Abdel Razek et al., 2006; Nouar, 2011). Our study, that was carried out at the largest national fishing port Béni Saf port, located in the Algerian west coast, where we examined the stomach content of 641 shrimps to determine their diet.

\section{Materials and Methods}

The shrimps used in this study come from the Algerian west coast, from the port of Beni Saf (Figure 1). The studies on the nature of the fishing grounds show that the seabed of this region forms the most extensive continental shelf on the Algerian coast since it extends up to 10 miles from the coast, and it is characterized by more or less coarse shell sand bottoms, and soft and black mud bottoms, which continue to the limit of the continental shelf (Leclaire, 1972). In this area, the shrimps are fished at depth between 150 and 450 meters. A total of 641 specimens were sampled monthly between September 2018 and August 2019 including 407 females and 234 males. Landings of the shrimp Parapenaeus longirostris are generally sorted into three size classes: small (4.50$7.50 \mathrm{~cm})$, medium $(8-10 \mathrm{~cm})$ and large $(10-14 \mathrm{~cm})$. The minimum merchant size of this species is $2 \mathrm{~cm}(\mathrm{MPRH}, 2004)$. In the laboratory, the shrimp were weighed and eviscerated individually. The entire digestive tract of each crustacean was removed and stored in $10 \%$ formalin. The diet was determined by emptying the contents into a petri dish, the identification of prey was carried out using a binocular microscope. The ingested preys were counted and according to their state of digestion were classified according to different taxonomic levels (class, order, family, genus and species). Unidentified preys were classified into various group due to their advanced state of digestion, that also included sediment, net, scales and eggs of fish. 


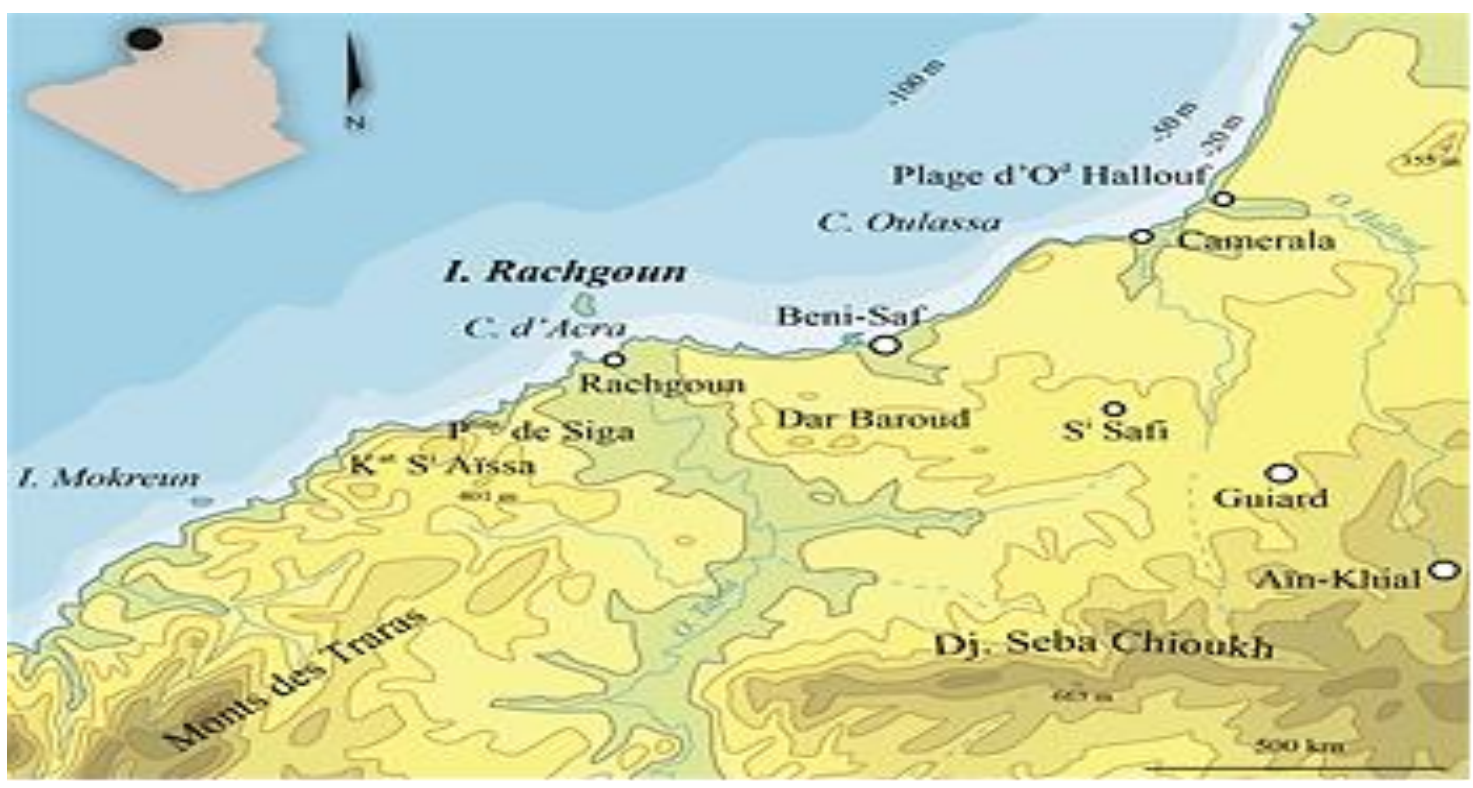

Figure 1. Geographical location of the Béni Saf Bay.

The diet has been studied from a qualitative (prey identification) and quantitative (numerical food indices) point of view, to assess the trophic state. We calculated some coefficients, namely:

Vacuity coefficient (Cv): it expresses the percentage of number empty stomachs (E) compared to the total number of stomachs (N) according to the formula given by Morato et al. (2000):

$\mathrm{CV}=\frac{\mathrm{E}}{\mathrm{N}} \times 100$

Frequency of preys (F): the ratio between the number of stomachs containing a category of prey $(n)$ and the total number of examined stomachs $(\mathrm{N})$, expressed as a percentage (Sorbe, 1972):

$\mathrm{F}=\frac{\mathrm{n}}{\mathrm{N}} \times 100$

Percentage in number $(\mathbf{C n})$ : the ratio between the number of individuals of a given prey $(A)$ and the total number of the various ingested prey $(\mathrm{B})$, expressed as a percentage:

$\mathrm{C}=\frac{\mathrm{A}}{\mathrm{B}} \times 100$

Average number of preys per stomach $(\mathbf{N m})$ : the ratio between the total number of the various ingested preys $(\mathrm{R})$ and the total number of examined stomachs $(\mathrm{N})$ :

$\mathrm{Nm}=\frac{\mathrm{R}}{\mathrm{N}}$

Statistical tests are performed to support the interpretation of the results.

\section{Results and Discussion}

The diet of Parapenaeus longirostris is very diverse. A total of 2550 ingested preys were identified, 641 stomachs were examined, from which 55 were empty (Table 1).

Table 1. Number of examined stomachs of Parapenaeus longirostris by season and sex.

\begin{tabular}{|c|c|c|c|c|c|c|c|c|c|}
\hline \multirow{3}{*}{$\begin{array}{l}\text { Sex } \\
\text { Fall }\end{array}$} & \multicolumn{3}{|c|}{$\begin{array}{c}\text { Total number of examined } \\
\text { stomachs }\end{array}$} & \multicolumn{3}{|c|}{$\begin{array}{l}\text { Number of full } \\
\text { stomachs }\end{array}$} & \multicolumn{3}{|c|}{$\begin{array}{l}\text { Number of empty } \\
\text { stomachs }\end{array}$} \\
\hline & $\hat{0}$ & q & $\hat{o}+q$ & $\hat{0}$ & o & $\hat{0}+q$ & $\hat{0}$ & q & $\hat{o}+q$ \\
\hline & 16 & 24 & 40 & 16 & 20 & 36 & 0 & 4 & 4 \\
\hline Winter & 103 & 136 & 239 & 100 & 128 & 228 & 3 & 8 & 11 \\
\hline Spring & 49 & 185 & 234 & 21 & 178 & 199 & 28 & 7 & 35 \\
\hline Summer & 66 & 62 & 128 & 65 & 58 & 123 & 1 & 4 & 5 \\
\hline Total & 234 & 407 & 641 & 192 & 407 & 586 & 32 & 23 & 55 \\
\hline
\end{tabular}

The average number of preys per stomach is (3.97\%). The values of vacuity coefficient (the percentage of empty stomachs in relation to the total number of analyzed stomachs) are calculated separately for each sex and by season (Figure 2). The value of vacuity coefficient $(\mathrm{Cv})$ is low in summer and winter. In spring, there is a rapid increase in this coefficient, especially for males (57.14\%). In general, males have a higher vacuity index $(13.67 \%)$ than females $(5.65 \%)$.

The average values of the vacuity coefficient during the four seasons are $(13.67 \%)$ for males and (5.65\%) for females. This difference is confirmed statistically by Student's $t$ test $(t=0.001 ; P<0.000)$. There is a significant difference between the average values of the vacuity coefficient in the two sexes. The variations of the vacuity coefficient according to the seasons show a minimum value of this coefficient in summer (3.9\%) and maximum in spring (14.95\%). The chi-square test confirms that there is a relationship between seasonal variations and $\mathrm{Cv}(\mathrm{X} 2=36 ; \mathrm{P}<0.05)$. These results show that the shrimps feed intensively in spring and less in winter and summer, which corresponds to an important food activity for the reserves constitution for reproduction. In addition, we notice an increase in the vacuity coefficient in autumn (decrease in food activity). This increase may be caused by the lack or low availability of food during this season. Females have a high feeding intensity $(\mathrm{CV}=5.65 \%)$ compared to males $(\mathrm{Cv}=13.67 \%)$, this can be explained by the fact that females have to consume more energy for the maturation of their gonads. 
(were observed for the whole year) (Ainouche, 2009). Crustacea, Foraminifera, Annelida Polychaeta, Mollusca and the various group are quantitatively the majority.

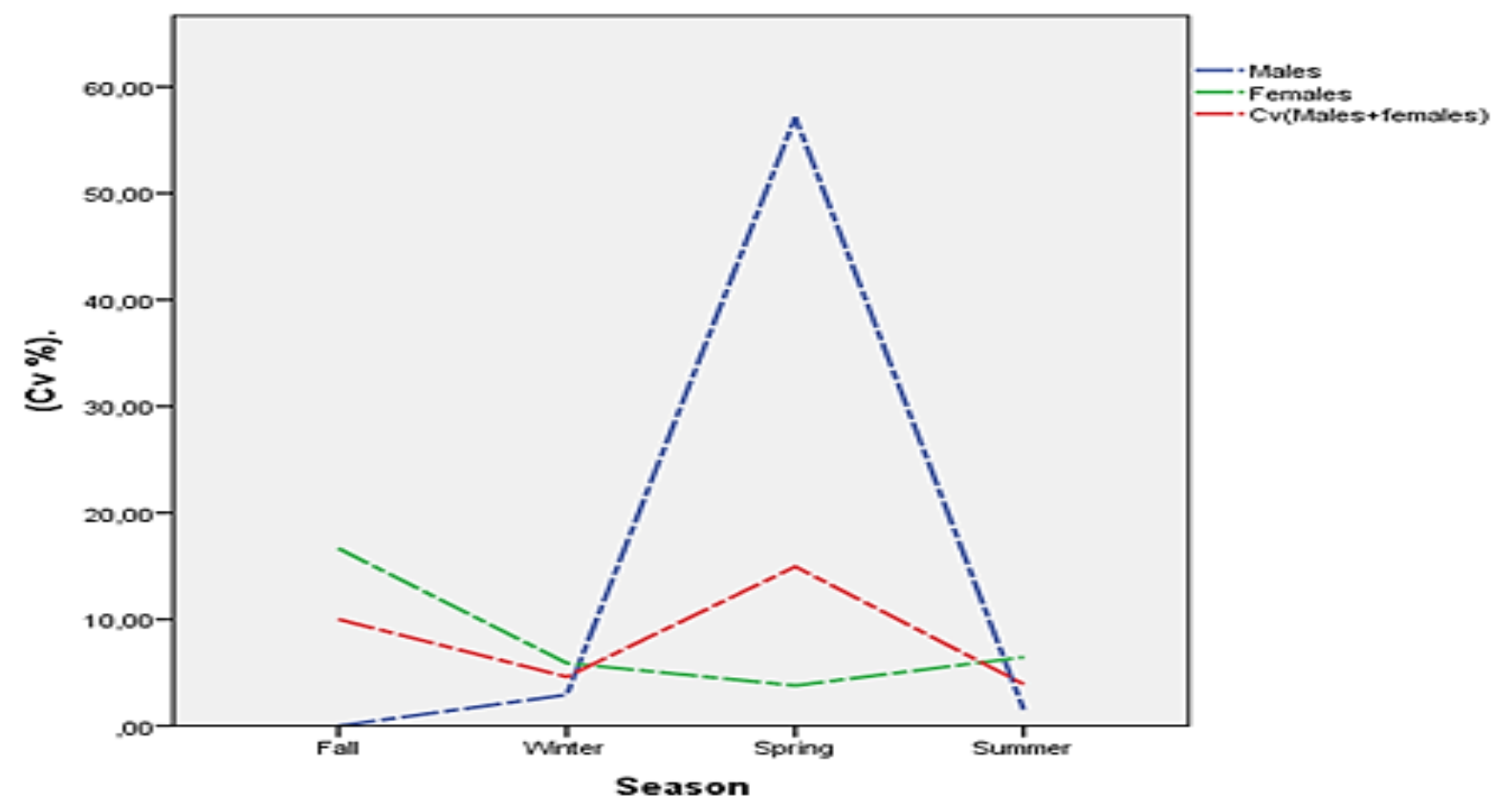

Figure 2. Seasonal evolution of the vacuity coefficient (Cv).

These organisms are associated with plant debris and sediment grains (Table 2). The sediment that is composed of organic material, mud or sand cannot be considered as food but as an element accompanying prey (Nouar, 2011). The diet of Parapenaeus longirostris consists mainly of Crustacea $(\mathrm{F}=77.69 \%$ and $\mathrm{Cn}=26.39 \%)$, followed by Foraminifera $(\mathrm{F}=77.22 \%$ and $\mathrm{Cn}=24.03 \%)$, Annelida Polychaeta ( $\mathrm{F}=58.50 \%$ and $\mathrm{C} n=16.39 \%)$, and Mollusca $(\mathrm{F}=52.73 \%$ and $\mathrm{C} n=17.41 \%)$. The other prey groups ranked in descending order by importance which are fish, Radiolaria, Porifera and Echinodermata (Figure 3). The value of frequency classifies the different groups of prey into three categories (Sorbe, 1972), and that expresses the predator's affinity to the prey:

- F $\geq 50 \%$ : Preferential prey

- F $10 \leq \mathrm{F} \leq 50 \%$ : Secondary prey

- F $\leq 10 \%$ : Accidental prey

Foraminifera seems to be the preferred prey of this species. Crustacea, Annelida Polychaeta and Mollusca are also preferred as well. The rest of the preys are accidental and are only eaten when food is unavailable. Deep water Parapenaeus longirostris additionally consumes benthic organisms in advanced deterioration situation. The diet of this species (Figure 4), depends on the distribution of the benthic fauna during each season. The increase in the size of the predator is correlated with an increase in the size of the prey. Parapenaeus longirostris proves trophic diversity and consumes a wide range of preys. This species is considered to be active and carnivorous predator towards benthic and endobenthic preys, in accordance with other work carried out in the Mediterranean and the Atlantic (Massuti, 1959; Ribeiro-Cascalho \& Arrobas, 1983; Lbropoulou \& Kostikas, 1999; Kapiris, 2004; Nouar, 2011).

Table 2. Shrimp diet composition.

\section{Preys}

Foraminifera

Discorbis bertheloti

Discorbis mamilla

Globigerina bulloides

Nonion granssum

Uvigerina peregrina

Annelida polychaeta

Glycerasp

Various annelids

Crustacea

Cladocerans

Amphipods

Copepods

Euphausiids

Isopods
Abundance (A*) Frequency of preys (F\%) Number of preys

77.22

19.03

14.50

12.63

18.09

116

83

375

105

270

498

39

64

41

46

35
12.94

58.50

16.38

42.12

77.69

6.08

9.98

6.39

7.17

5.46
613

143

126

94

148

102

418

132

286

673

68

69

66

47

Percentage by number

(Cn\%)

24.03

5.60

4.94

3.68

5.80

4

16.39

5.17

11.21

26.39

2.66

2.70

2.58

1.84

3.05 
Ukrainian Journal of Ecology

\begin{tabular}{|c|c|c|c|c|}
\hline Ostracods & 41 & 6.39 & 81 & 3.17 \\
\hline Decapods & 74 & 11.54 & 89 & 3.49 \\
\hline Decapod larvae & 83 & 12.94 & 90 & 3.52 \\
\hline Amphipod larvae & 75 & 11.70 & 85 & 3.33 \\
\hline Mollusca & 338 & 52.73 & 444 & 17.41 \\
\hline Bivalves & 84 & 13.10 & 112 & 4.39 \\
\hline Cephalopods & 86 & 13.41 & 92 & 3.60 \\
\hline Gastropod larvae Mollusk & 92 & 14.35 & 108 & 4.23 \\
\hline Egg & 76 & 11.85 & 132 & 5.17 \\
\hline Echinodermata & 12 & 1.87 & 23 & 0.90 \\
\hline Echinoderm Larva & 12 & 1.87 & 23 & 0.90 \\
\hline Radiolaria & 18 & 2.80 & 27 & 1.05 \\
\hline Porifera & 12 & 1.87 & 32 & 1.25 \\
\hline Pisces & 31 & 4.83 & 94 & 3.68 \\
\hline Fish larvae & 31 & 4.83 & 94 & 3.68 \\
\hline Plant debris & 74 & 11.54 & 96 & 3.76 \\
\hline Various & 116 & 18.09 & 130 & 5.09 \\
\hline
\end{tabular}

$A^{*}$ - Taxonomic identification was used with many preys.

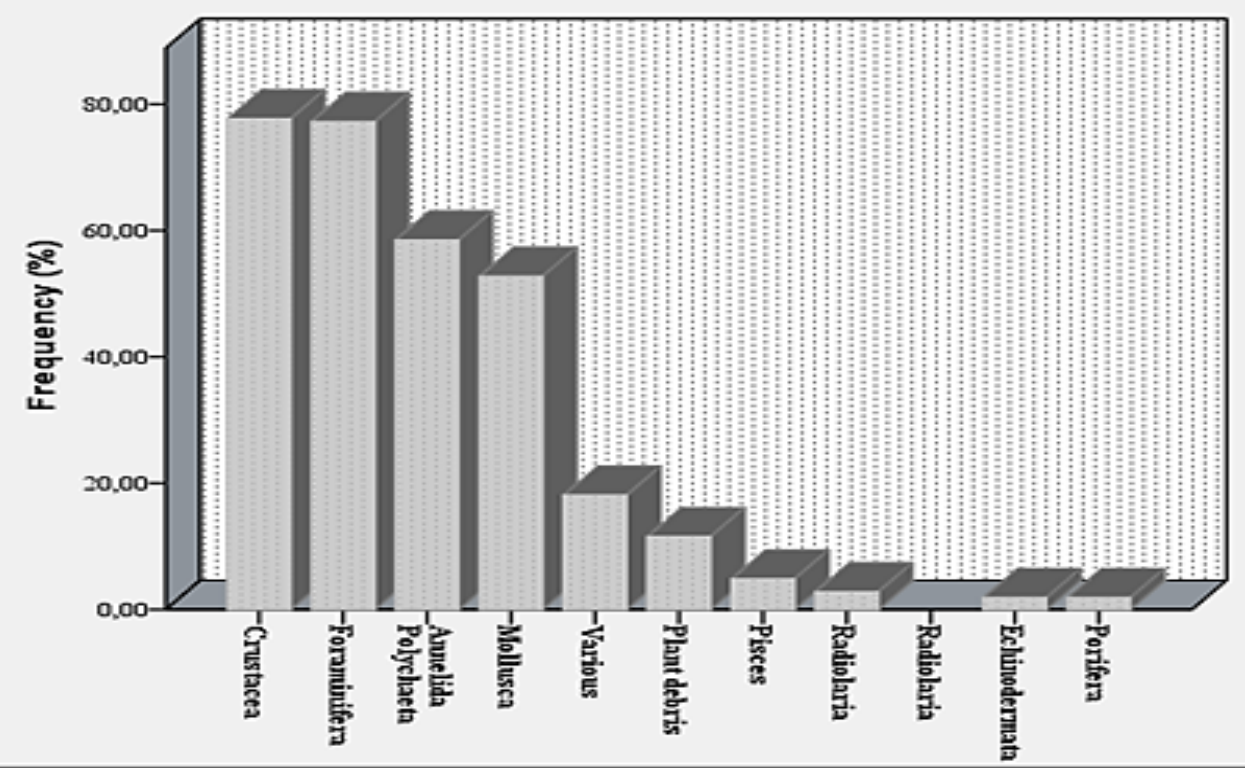

Figure 3. Frequency $(F, \%)$ of the different preys consumed by Parapenaeus longirostris.
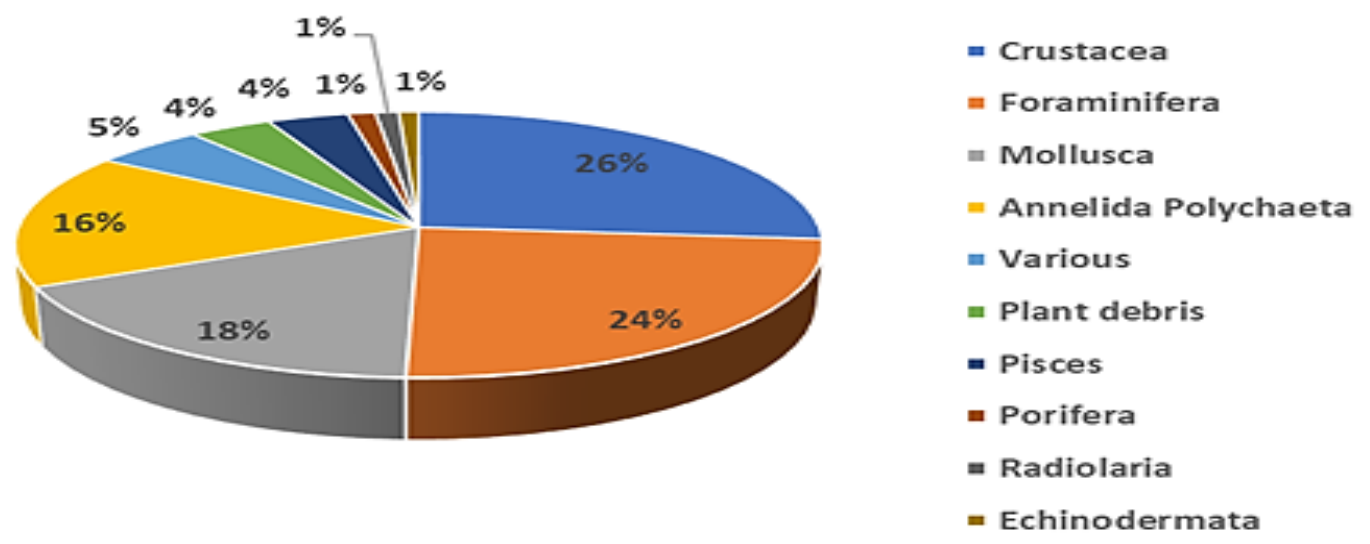

Figure 4. Parapenaeus longirostris diet composition (Cn, \%). 
The diet of Parapenaeus longirostris varied with specimen size. The analysis displays prey selectivity in relation to the size classes. Small shrimps $(4.5-7.5 \mathrm{~cm})$ show preference for Annelida Polychaeta, while the medium $(8-10 \mathrm{~cm})$ and large $(10-14 \mathrm{~cm})$ shrimps preferred Foraminifera and Mollusca. The Crustacea were the dominant prey in all size classes (Figure 5).

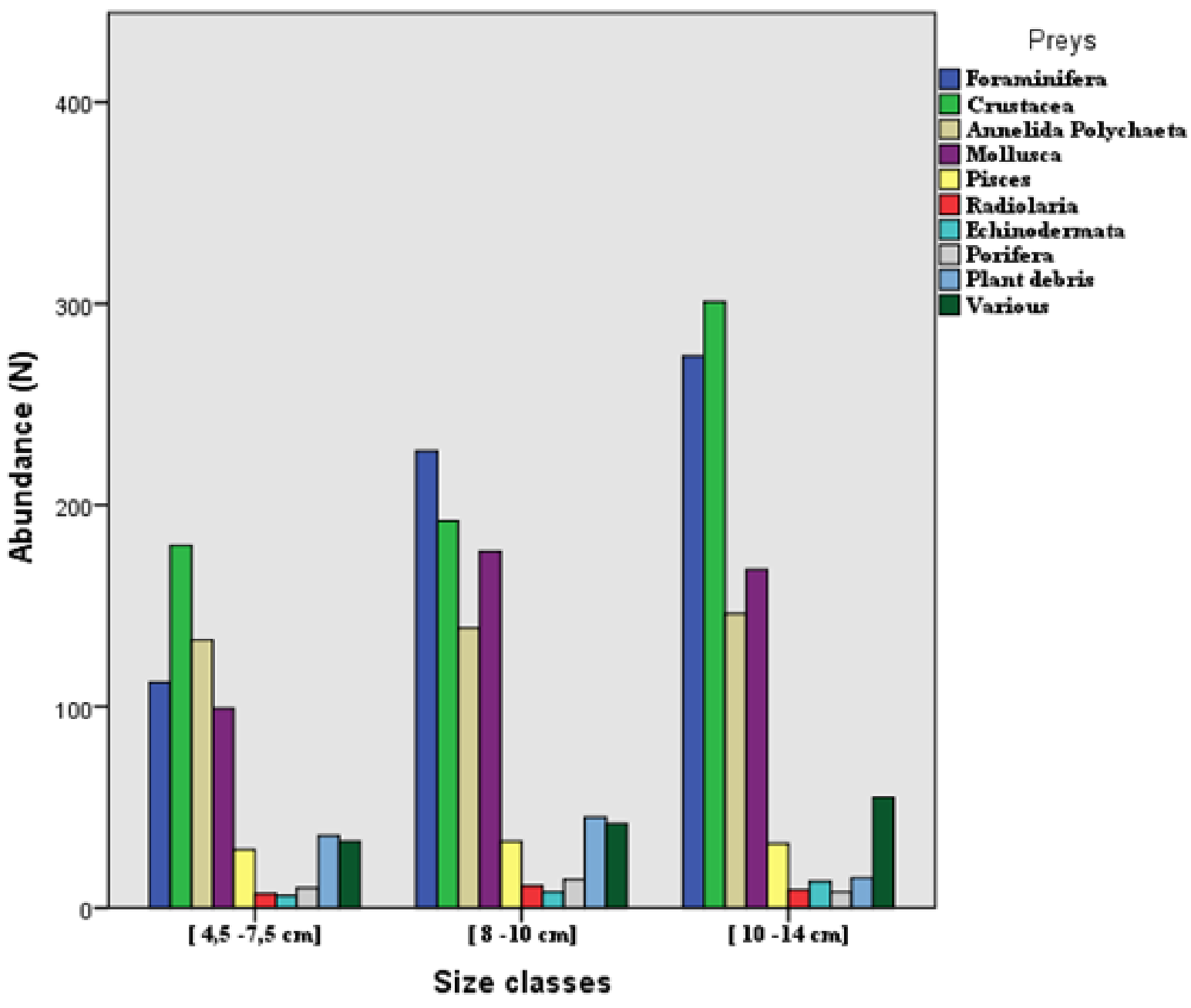

Figure 5. Variations in the abundance $(\mathrm{N})$ of prey according to the size classes of Parapenaeus longirostris.

The composition of the diet by prey category varies significantly in number depending on the size class of fish ( $x 2=6$, d.d.I. $=4$, $\mathrm{P}<0.001$ ). The global analysis of the distribution of the large groups of prey (Table 3) according to the size classes of Parapenaeus longirostris highlights very significant differences in abundance $(\mathrm{N}=2550, \mathrm{P}>0.05$, d.d.I. $=18)$, which shows an identical distribution of prey compared to the size classes.

Table 3. The abundance $(\mathrm{N})$ of the main prey categories according to the size classes of Parapenaeus longirostris (d.d.I.=4).

\begin{tabular}{lllll}
\hline Size classes & $\mathbf{4 . 5 - 7 . 5} \mathbf{~ c m}$ & $\mathbf{8 - 1 0} \mathbf{~ c m ~}$ & $\mathbf{1 0 - 1 4} \mathbf{~ c m}$ \\
Number of preys & $641^{*}$ & $888^{*}$ & $1021^{*}$ \\
Number of stomachs & 104 & 225 & 312 \\
\hline
\end{tabular}

*The values significant at $\mathrm{P}<0.001$

Food intake differs according to age and larger individuals are more efficient predators due to their great swimming ability and the increase in food biodiversity seems to be more evident. Food intake of small individuals is composed mainly of foraminifera and planktonic crustacea, on the other hand in addition to foraminifera, the adults consume larger preys. The diet differs according to the season and depending on the availability and distribution of prey during each season (Figure 6). The temporal distribution of prey is statistically different from one season to another and can be justified by an ANOVA analysis: (Fobs=6.35, d.d.I=3, $p=0.0014$ ). There is a significant difference in prey averages between seasons. Kapiris (2004) attributes the seasonal variations to metabolic activities of the species such as molting and reproduction. In fact, spring corresponds to the Parapenaeus longirostris's gonads maturation period.

Kappiris in 2004, assumed that the diet in this species is very variable, very diverse and composed mainly of benthic, endobenthic and bathypelagic species. Foraminifera, Annelida Polychaeta and crustacea are considered the main prey categories of this species. The great diversity of prey makes it possible to consider its omnivorous diet (Moriarty, 1977; Sobrino et al., 1989 and 1994 ; Nouar, 2011). 


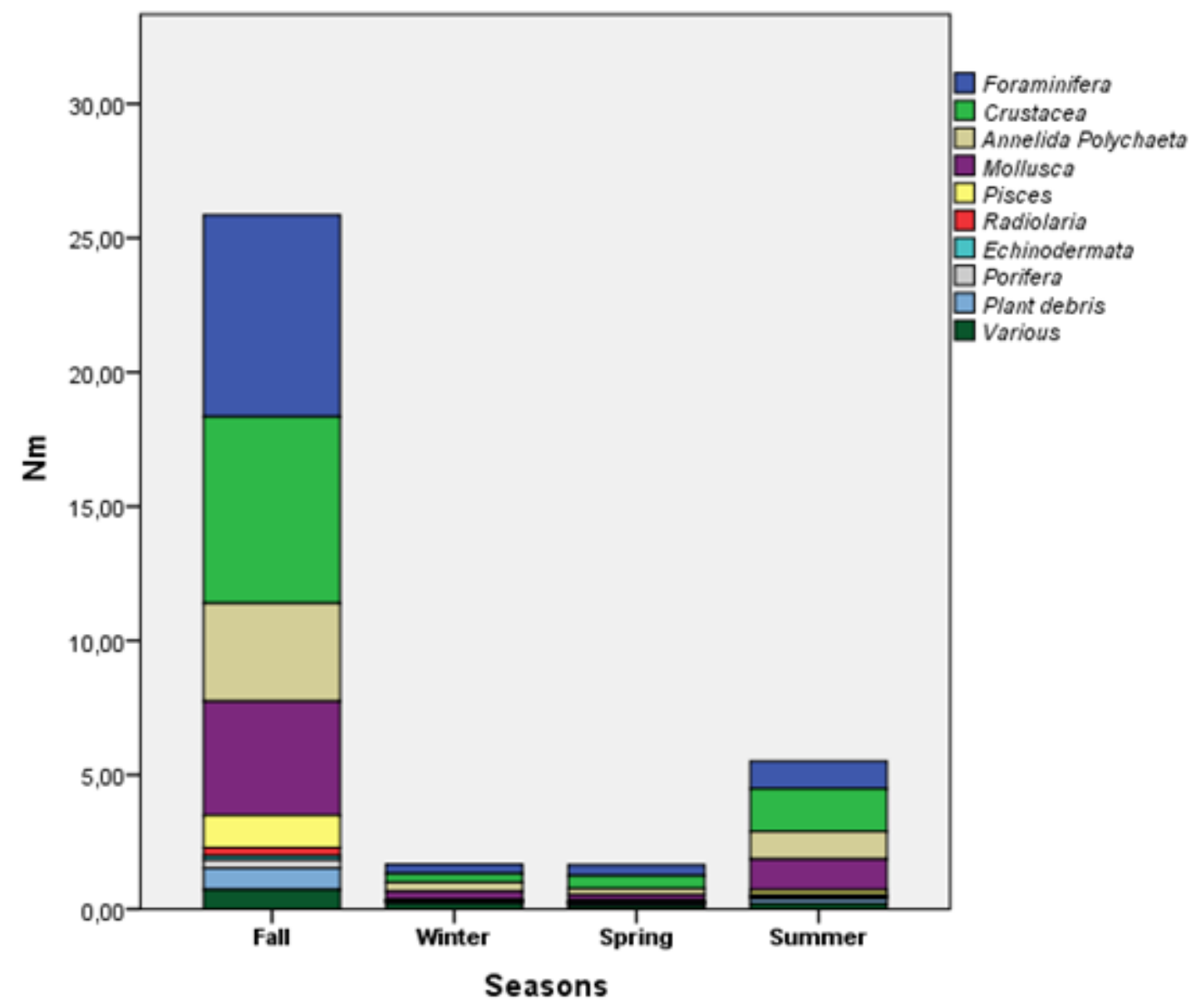

Figure 6. Seasonal variation in the mean of prey $(\mathrm{Nm})$ per stomach.

\section{Conclusion}

This research is the first study on the diet of Parapenaeus longirostris in western Algeria and the main objective is to fill the gaps in the biology of this species. The deep-water rose shrimp frequents the entire Algerian continental shelf, from $220 \mathrm{~m}$ to $640 \mathrm{~m}$ deep. Its diet consists of a wide variety of animal species and plant debris and its preferred preys are mainly benthic and endobenthic such as Foraminifera, Crustacea, Annelida Polychaeta and Mollusca are also preferred prey. Plant debris, copepods, amphipods, euphausiids, eggs and larvae of decapods and molluscs, crabs, gastropods, scales and eggs of fish, grains of sand, Porifera, and Radiolaria, are considered more or less important part of the diet of this species. Food biodiversity appears to increase with age for both sexes. Diet depends on the availability and distribution of prey during each season and it differs only slightly depending on gender or season.

\section{References}

Abdel Razek, F.A., El-Sherief, S.S., Taha, S.M. \& Muhamad, E.G. (2006). Some biological studies of Parapenaeus longirostris (Lucas, 1846) (Crustacea, Decapoda) in the Mediterranean coast of Egypt. Egyptian Journal of Aquatic Research, 32 (1), $385-400$.

Ainouche, N. (2009). Ecologie, biologie et exploitation de la crevette Parapenaeus longirostris (Lucas, 1846) de la région algéroise. Mémoire de magister en écologie et environnement marin : Océanographie biologique et environnement marin, USTHB Alger (in French).

Benkabouche, I. (2015). Biologie et dynamique de la population de la crevette rose Parapenaeus longirostris (Lucas, 1846) pêchée au niveau de la côte oranaise. Thèse de doctorat en gestion des ressources halieutiques, université d'Oran (in French).

Froglia, A. (1982). Contribution to the knowledge of the biology of Parapenaeus longirostris

(Lucas) (Decapoda, Penaidea). Quad. Lab. Tecnol. Pesca, 3 (2-5), 163-168.

Gheid, S. (2015). Apport nutritionnel de Penaeus kerathurus (Crustacé, Décapode): Effet de quelques facteurs polluants. Thèse de doctorat en biologie animale, Université Badji Mokhtar, Annaba (in French).

Ghidalia, W., Bourgeois, F. (1961). Influence de la température et de l'éclairement sur la distribution des crevettes des moyennes et grandes profondeurs. CGPM, 16, 42 (in French).

Kapiris, K. (2004). Feeding ecology of Parapenaeus longirostris (Lucas, 1846) (Decapoda: Penaeidae) from the Ionian Sea (central of Eastern Mediterranean Sea). Scientia marina, 68 (2), 247-256.

Labropoulou, M., Kostikas, I. (1999). Patterns of ressourceuse in deep-water decapods. Mar. Ecol. Prog. Ser., 184, $171-182$.

Lagardere, J.P. (1975). Recherches sur l'alimentation des crevettes bathypélagiques du talus continental du golfe de Gascogne. Rev. Tvav. Inst. Pêches marit., 39 (2), 213-229 (in French).

Leclaire, L. (1972). La sédimentation holocène sur le versant méridional du bassin Algéro-Baléares (Précontinent algérien). Mémoires du Muséum National d'Histoire Naturelle, XXIV (in French).

Massuti, M. (1959). La gamba Parapenaeus longirostris (Lucas). Primera observciones en los Calderosdelgolfo de Cadiz y africa occidentales. Invest. Pesq, XV, 51-80 (in French). 
Moriarty, D.J.W. (1977). Quantification of Carbon, Nitrogen and bacterial biomass in the food of some Penaeid prawns. Aust. J. Mar. Fresh. Res, 28, 113-118.

MPRH, (2004). Rapport annuel du ministère de la pêche et des ressources halieutiques, Alger (in French).

Nouar, A. (1985). Contribution à l'étude de la crevette Pénéide Parapenaeus longirostris (Lucas, 1846) dans la région d'Alger: Ecologie, biologie et exploitation. Thèse de Magister. Spécialité Oceanographie: option halieutique, USTHB Alger. (in French).

Nouar, A., Maurin, C. (2001). Nature of and typical populations on the characteristic facies of substratum of Parapenaeus longirostries (Lucas, 1846) along the Algerian coast. Crustaceana, 74 (2), 129-135.

Nouar, A. (2011). Régime alimentaire de la crevette rose Parapenaeus longirostris (Lucas, 1846) (Crustacea: Decapoda) des fonds chalutables de la région d'Alger. Numéro spécial du bulletin du CNDRB "Biodiversité des côtes algériennes"), 86-89 (in French).

Ragonese, S., Di Stefano, L., Bianchini, M.L. (2000). Catture e selettivita` di pesci cartilaginei nella pesca dei gamberi rossi nello Stretto di Sicilia. Biologia Marina Mediterranea, 7, 400-411 (in French).

Ragonese, S., Bianchini, M.L. (2006). Trawl selectivity trials on the deep-water rose shrimp (Parapenaeus longirostris) in Sicilian waters. Hydrobiologia, 557, 113-119.

Thessalou-Legaki, M. (2006). Issues of Decapod Crustacean Biology. Springer, Doi: 10.1007/s10750-005-1314-y.

Ribeiro-Cascalho, A., Arrobas, I. (1983). Further contributions to the knowledge about biology and fishery of Parapenaeus longirostris (Lucas, 1846) of south Portuguese coast. ICES CM, 11983 (:K), 26.

Sobrino, I.., Cervantes, A. (1989). Contribucion al conociemiento de los parametros biologicos de la Gamba blanca (Parapenaeus longirostris, Lucas, 1846) de la division 34.1.1. De COPACE. Centr.Océanogr, VI (1_, 59-76 (in French).

Sobrino, I.., Garcia, T. (1994). Biology and fishery of the deep water rose shrimp Parapenaeus longirostris (Lucas, 1846) from the Atlantic Moroccan coast. Sci. Mar, 58 (4), 299-305.

Sorbe, J.C. (1972). Ecologie et éthologie alimentaire de l'ichtyofaune chalutable du plateau continental Sud-Gascogne. Thèse UER scienes de la mer et de l'environnement. Université d'Aix-Marseille. Doctorat 3ème cycle. (in French).

\section{Citation:}

Benallal, A.M., Baaloudj, A., Kerfouf, A., Bouzidi, M.A., Belhadj Tahar, K. (2020). Natural diet of deep-water rose shrimp in the Beni-Saf Bay (Western Algeria). Ukrainian Journal of Ecology, 10 (4), 109-115. 